\title{
Impact of International Trade, Remittances and Industrialization on the Economic Growth of Bangladesh
}

\author{
Jannatul Ferdaous \\ Bangladesh University of Professionals, Dhaka, Bangladesh \\ Qamruzzaman ACMA \\ Southeast university, Dhaka, Bangladesh
}

\begin{abstract}
There are several important factors of growth and many endeavors have been made to apply these factors to explain the growth of different economies at different times. In this context, the objective of this paper is to examine the impact of international trade, remittances and industrialization on the economic growth of Bangladesh using annual data from the period of 1976 to 2010. This study uses the time series econometrics methodology, which covers tests for stationary, cointegration, and specification of the model. This study also focuses on finding causal relationship among export, import, remittances, and industrialization on the economic growth of Bangladesh by using Granger causality test. The result shows that the variables are cointegrated, implying a long-run causal relationship among export, import, remittances, and industrialization on the economic growth of Bangladesh.
\end{abstract}

Keywords: export, import, industrialization, remittances, economic growth

\section{Introduction}

Bangladesh is a developing economy of South Asia which is emerged as an independent nation in 1971 with a population of 150 million. The country's fundamental economic policy is aimed at achieving high and steady growth, reducing extensive poverty, and sustaining macroeconomic stability. In this process, export growth is often considered to be a principal determinant of production and employment growth in an economy. Export in particular improves the economic growth through adopting foreign technologies and increasing capital utilization and merits of economies of scale. Generally, export helps to remove foreign exchange hurdles and can thereby provide greater access to international market. In the early years after independence in 1971, Bangladesh embarked on an inward-oriented development strategy. Accordingly, higher tariffs and quota were imposed on imports. This in turn created an anti-export bias within Bangladesh economy. However, since 1980s, the policy regime shifted toward export-promotion from import substitution. Tariff rates were reduced and quotas were also abolished gradually. Industrial and trade policy was focused to promote export. Financial incentives are provided, in the form of tax exemption, on exportable commodities. Exclusive Export Processing Zones (EPZs) are established to attract foreign direct investment and export promotion. Foreign firms, investing

Jannatul Ferdaous, Ph.D., assistant professor, faculty of business studies, Bangladesh University of Professionals, Dhaka, Bangladesh.

Qamruzzaman ACMA, Master of Degree, senior lecturer, School of business studies, Southeast university, Dhaka, Bangladesh.

Correspondence concerning this article should be addressed to Md. Qamruzzaman ACMA, House \#64, Road \#18, Main Building, Banani, School of Business Studies (SBS), Southeast University, Dhaka, Bangladesh. E-mail: qzamanfindu@gmail.com. 
in EPZs, get special preference and tax exemption facilities. State-owned enterprises, nationalized in the early 1970s, are privatized or are in the process of privatization (Ahmed, 2001).

There has been a structural change in the Bangladesh economy over the past decades. Bangladesh has witnessed a respectable growth record in its real Gross Domestic Product (GDP), as well as, in various sectors. In 1970s, the average GDP growth rate was $2.3 \%$ which was increased to $4.8 \%$ from 1970 s to 1980 s and further increased to $6.3 \%$ between 1980s and 1990s (World Bank, 2005). It was predominantly observed that the agricultural sector's contribution in GDP declined from $32.0 \%$ to $18.64 \%$ from 1981 to 2009 ; on the other hand the share of industrial sector in GDP increased from $22.0 \%$ to $28.61 \%$ in 2009 . Furthermore, country has also experienced a change in its export composition - from primary commodities to manufacturing goods (Love \& Chandra, 2005).

Imports of intermediate goods, industrial raw materials, and capital machinery have risen over the years. Remittance is another most important source of foreign earnings for Bangladesh. According to a study, it is estimated that the required level of remittances in fiscal year (FY) 2020 for consistent 4\%, 6\%, and 8\% GDP growth will be US\$8.9 billion, US\$16.4 billion, and US\$29.9 billion respectively (Ahmed \& Uddin, 2009).

The future growth of Bangladesh is depending on promoting export, sustaining remittances, and triggering industrialization. Figure 1 demonstrates the growth rate of real GDP, exports and real imports, workers remittances and industry value added of Bangladesh. It can be seen that the growth rates were volatile in the period between 1976 and 1986. However, after 1986 the growth rates were less volatile than the period between 1976 and 1986.

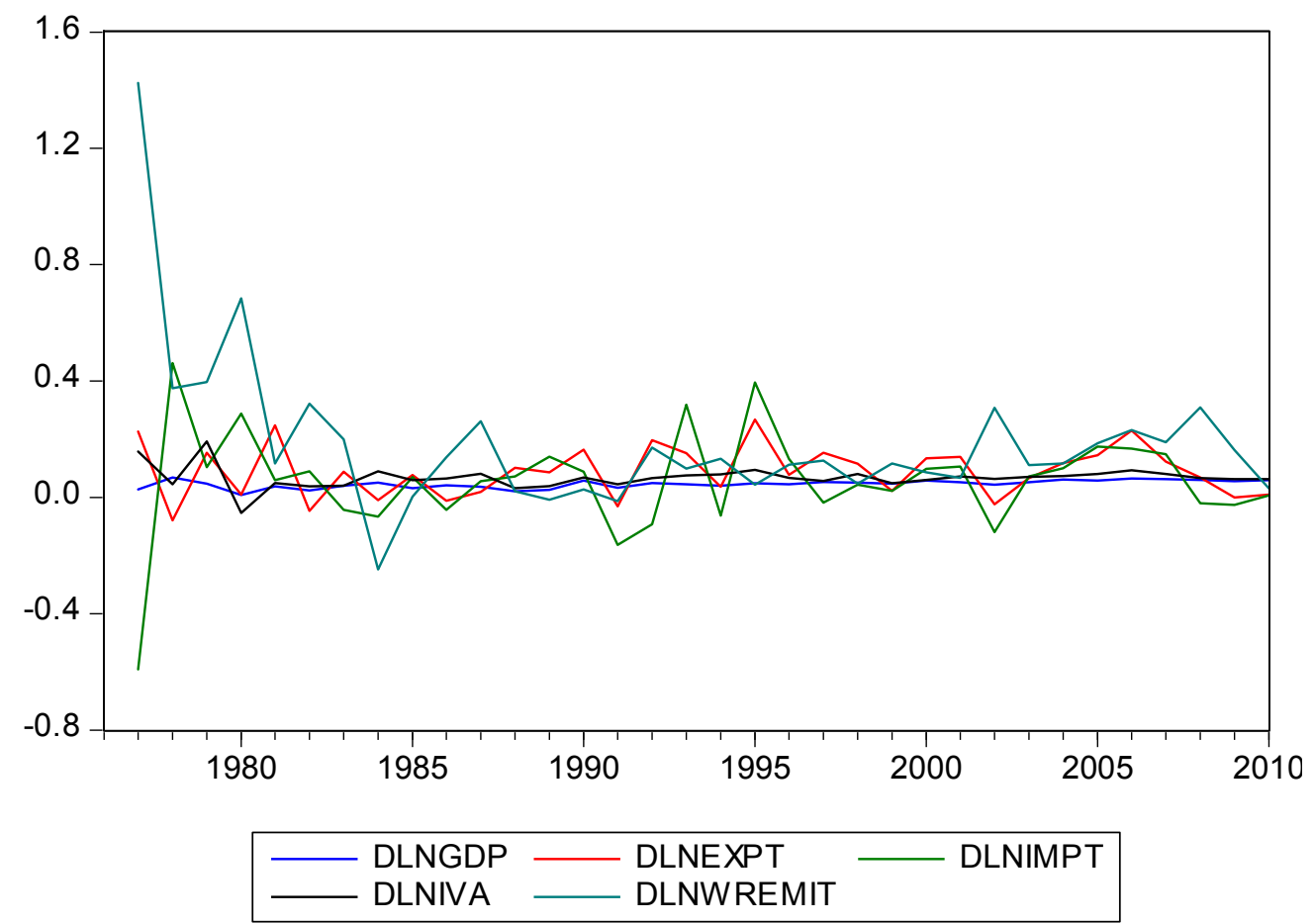

Figure 1. Growth rate of $\operatorname{lnGDP}$, lnEXPT, lnIMPT, lnWREMIT, and lnIVA of Bangladesh. Source: Author calculation.

A number of empirical researches have been conducted to investigate the nexus between exports and growth in Bangladesh over the period. Few of those are stated below with a view to identify research gap as well as to gain conceptual understanding for further research simultaneously. 
Abual-Foul (2010) conducted study finding a relationship among export, domestic demand and economic growth in Nigeria with application of Granger causality and cointegration test. Study result revealed that economic growth found Granger-cause relations between export and domestic demand, while domestic demand (proxied by government consumption) was seen to have been caused by export. There was a bilateral causality existing between export and household consumption - another proxy for domestic demand which suggests that domestic demand is a veritable tool that encourages engagement of the country (Nigeria) in international trade.

Mamun and Nath (2005) examined time series evidence to investigate the link between exports and economic growth in Bangladesh. Applying quarterly data for a period from 1976 to 2003, the article ascertains that industrial production and exports are cointegrated.

Judith and Ralhan (2005) conducted research considering error correction model (ECM) to investigate relations among export growth, economic growth, and trade policy. Study result revealed that there is a long-run unidirectional causality from exports to growth in Bangladesh. Trade policies are integrated with economic growth and development strategies. Therefore, the linkage between trade policy and development cum industrialization strategy is crucial.

Shirazi and Manap (2005) observed the export-led growth (ELG) hypothesis for five South Asian countries including Bangladesh using cointegration and multivariate Granger causality tests. The authors found feedback effects between exports and GDP and imports and GDP for Bangladesh.

Remittance comprises a significant source of foreign exchange for the poor countries which have extensive development impact. From macro frontier, remittances are used to make import payments and are used for productive investment by the government. World Bank identified overseas remittances achieving a favorable balance of payments and as well as creating a new resources base for the country. The steady flow of remittances has resolved the foreign exchange constraints, has improved the balance of payments, and also helped to increase the supply of national savings (Quibria, 1986). The contribution of remittance to GDP has also grown from a $1 \%$ in $1977-1978$ to $5.2 \%$ in 1982-1983. During the 1990 s, the ratio was around $4 \%$. However, if one takes into account the informal flow of remittances, its contribution to GDP would definitely be much higher. Mah (2005) ascertained that an increase in remittance by Taka 1 would result in an increase in national income by Taka 3.33. Garments manufacturing is treated as the highest foreign exchange earning sector of the country (US\$4.583 billion in 2003). However, if the cost of import of raw material is adjusted, in that case the net earning from migrant workers' remittances is higher than that of the garments sector. In 2003, the earning from remittance is net US\$3.063 billion, whereas net export earning from RMG stood between US\$2.29 and US\$2.52 billion. In 1998-1999, 22\% of the official import bill was financed by remittances (Khan, 2002). Remittance is a major source of foreign earnings for any country. Bangladeshi workers send an enormous amount of foreign currency in the country, sometimes the amount of foreign currency surpassed the export earnings from goods and services. The paper discusses how to improve the short-run and long-run impact of remittance, export and import on the GDP growth of Bangladesh by using the cointegration and Granger causality in a vector error correction model (VECM) framework to analyze the relationship (Ahmed \& Uddin, 2009).

A country's trade is closely related to its stage of development and degree of industrialization. Sultan (2008) examined that only export and/or import cannot contribute to the economic growth unless industrial sector is taken into account. As a nation advances economically, the structure of its foreign trade alters to correspond with a shifting pattern of recourses endowment and comparative advantage. The literature, which 
has an extensive inventory of models that stress the importance of trade in achieving a sustainable rate of economic growth, emphasized on different variables, such as real exchange rate, degree of openness, tariffs, terms of trade and export performance etc., to verify the hypothesis that open economies grow more rapidly than those that are closed. It is commonly accepted that many East Asian countries have achieved higher rates of economic growth through export-led industrialization, however, the empirical evidence is commonly mixed. A vector auto-regressive model for USA, Taiwan, and Japan, is used to find economic growth: Granger-causes export growth in the USA, export-led growth in Taiwan and a feedback causal relationship exist in the case of Japan. The following Table 1 shows some empirical research works for finding research gap in order to identity variables and methodology in this regards.

Table 1

Summary of Empirical Research

\begin{tabular}{|c|c|c|c|c|}
\hline $\begin{array}{l}\text { SL } \\
\text { no }\end{array}$ & Authors & Variable & Methodology & Outcome \\
\hline 01 & $\begin{array}{l}\text { Mamun and Nath } \\
(2005)\end{array}$ & $\begin{array}{l}\text { exports, economic } \\
\text { growth }\end{array}$ & cointegration analysis & $\begin{array}{l}\text { The article ascertains that industrial production and } \\
\text { exports are co-integrated. }\end{array}$ \\
\hline 02 & $\begin{array}{l}\text { Shirazi and Manap } \\
(2005) \text { and Chandra } \\
(2003)\end{array}$ & exports, GDP, imports & $\begin{array}{l}\text { cointegration and } \\
\text { multivariate Granger } \\
\text { causality tests }\end{array}$ & $\begin{array}{l}\text { The authors found feedback effects between exports } \\
\text { and GDP and imports and GDP for Bangladesh. }\end{array}$ \\
\hline 03 & $\begin{array}{l}\text { Ahmed and Uddin } \\
(2008)\end{array}$ & $\begin{array}{l}\text { export, domestic } \\
\text { demand, economic } \\
\text { growth }\end{array}$ & $\begin{array}{l}\text { Augmented } \\
\text { Dickey-Fuller (ADF) } \\
\text { and Phillip-Perron (PP) } \\
\text { stationarity test as well } \\
\text { as Johansen and } \\
\text { Juselius cointegration }\end{array}$ & $\begin{array}{l}\text { Economic growth found Granger-cause relations } \\
\text { between export and domestic demand, while } \\
\text { domestic demand (proxied by government } \\
\text { consumption) was seen to have been caused by } \\
\text { export. }\end{array}$ \\
\hline 04 & $\begin{array}{l}\text { Khawaja and } \\
\text { Hiranya (2005) }\end{array}$ & $\begin{array}{l}\text { export growth, } \\
\text { economic growth, } \\
\text { trade policy }\end{array}$ & $\begin{array}{l}\text { error correction model } \\
(\mathrm{ECM})\end{array}$ & $\begin{array}{l}\text { Study found long-run unidirectional causality from } \\
\text { exports to growth in Bangladesh. Trade policies are } \\
\text { integrated with economic growth and development } \\
\text { strategies. }\end{array}$ \\
\hline 05 & Biru (2011) & $\begin{array}{l}\text { exports growth, } \\
\text { imports growth, real } \\
\text { output growth }\end{array}$ & $\begin{array}{l}\text { cointegration and } \\
\text { multivariate granger } \\
\text { Causality test }\end{array}$ & $\begin{array}{l}\text { The results show feedback effects between exports } \\
\text { and output growth and also between imports and } \\
\text { output growth in the short-run. A strong feedback } \\
\text { effects between import growth and export growth } \\
\text { has also been established. }\end{array}$ \\
\hline 06 & Perron (1990) & $\begin{array}{l}\text { export growth, } \\
\text { industrial } \\
\text { development }\end{array}$ & $\begin{array}{l}\text { multivariate Granger } \\
\text { causality test }\end{array}$ & $\begin{array}{l}\text { There is strong bi-directional causality between the } \\
\text { export growth and industrial development. }\end{array}$ \\
\hline 07 & $\begin{array}{l}\text { Darrat, Hsu, and } \\
\text { Zhong (2000) }\end{array}$ & $\begin{array}{l}\text { export performance, } \\
\text { economic growth }\end{array}$ & $\begin{array}{l}\text { simultaneous equation } \\
\text { model }\end{array}$ & $\begin{array}{l}\text { It finds strong evidence of bi-directional causality } \\
\text { between export growth and economic growth for } \\
\text { Pakistan. }\end{array}$ \\
\hline 08 & Abual-Foul (2010). & $\begin{array}{l}\text { export growth, } \\
\text { economic growth, } \\
\text { and trade policy }\end{array}$ & $\begin{array}{l}\text { multivariate Granger } \\
\text { causality test }\end{array}$ & $\begin{array}{l}\text { Study found long-run unidirectional causality from } \\
\text { exports to growth in Bangladesh. Trade policies are } \\
\text { integrated with economic growth and development } \\
\text { strategies. }\end{array}$ \\
\hline
\end{tabular}

It is obvious form the above literature review that a number of empirical researches have been conducted to investigate the nexus between exports and growth in Bangladesh over time. But the fact which does not motivate people to go further research on this area is limited number of variables used in each work; such limitation produces a research gap in regards to research scope and various indicators of economic development of Bangladesh.

This study has taken the impact of export, import, remittance, and industrialization on economic growth into account. The intend of this paper is to investigate short-run and long-run dynamic impact of exports, 
imports, remittance, and industrialization on GDP growth of Bangladesh, applying the cointegration and Granger causality in a Vector-Auto Regressive (VAR) framework to analyze the relationship.

The paper is organized in five parts besides this introduction and the review of the literature. Part 2 discusses data and methodology, part 3 presents the empirical analysis and highlights the analysis of the results, and part 4 concludes.

\section{Data and Methodology}

One of the objectives of this paper is to investigate the long-run dynamics relationship among the five variables, i.e. imports, exports, worker remittances, industrialization (industry value added), and economic growth (GDP). In this empirical study, exports and imports, worker remittances, and industrialization (industry value added) are used as independent variables and economic growth (GDP) as the dependent variable. The equation can be represented as follows:

$$
\operatorname{lnGDP}_{t}=\beta_{0}+\beta_{1} \operatorname{lnEXPT}_{t}+\beta_{2} \operatorname{lnIMPT}_{t}+\beta_{3} \operatorname{lnWREMIT}_{t}+\beta_{4} \operatorname{InIVA}_{t}+\varepsilon_{t}
$$

Where, the vectors (InGDP, InEXPT, InIMPT, InWREMIT, and lnIVA) represent log levels of real GDP, exports, imports, workers remittances, and industry value added at time $t$ (1976 to 2010). The constant and the coefficients of the regression equations are $\beta_{0}$ and $\beta_{1}, \beta_{2}, \beta_{3}$, and $\beta_{4}$ respectively; $\varepsilon_{t}$ is the error term.

\section{Data}

Annual data on real GDP, exports, imports, remittance, and industry value added from 1976 to 2010 are used for this paper. The data are in the constant US dollar. Real GDP, export, import and industry value added (base year 2000) data are collected from World development indicators (WDI) of the World Bank. Data on workers remittances are collected from Economic Trends and Economic Review and the web site of the Bangladesh bank. The summary statistics of the study variables are reported in Table 2.

Table 2

Summary Statistics of the Study Variables

\begin{tabular}{lcclcllll}
\hline & Mean & Min & Max & Std. Dev. & Skew-ness & Kurtosis & Jarque-Bera & Prob \\
\hline GDP & $39,197.31$ & $17,615.00$ & $82,979.00$ & $18,775.54$ & 0.828611 & 2.576182 & 4.267091 & 0.118417 \\
EXPT & $5,108.029$ & 769.0000 & $15,797.00$ & $4,826.511$ & 1.131544 & 3.015755 & 7.469314 & 0.023881 \\
IMPT & $7,025.343$ & $1,288.000$ & $17,346.00$ & $4,835.987$ & 0.929483 & 2.663271 & 5.204996 & 0.074088 \\
IVA & $9,252.371$ & $2,385.000$ & $23,677.00$ & $6,141.517$ & 0.895915 & 2.671966 & 4.839130 & 0.088960 \\
WREMIT & $2,240.143$ & 19.00000 & $10,838.00$ & $2,875.830$ & 1.910532 & 5.660703 & 31.61648 & 0.000000 \\
\hline
\end{tabular}

Source: Author's calculation using Eviews 8.0.

All the data used in the study are in logarithmic form. This transformation can diminish the problem of heteroscedasticity as log transformation compresses the scale in which the variables are measured. The variables (lnGDP, lnEXPT, lnIMPT, lnWREMIT, and lnIVA) refer to the natural log of gross domestic product, natural $\log$ of export, natural $\log$ of import, natural log of workers remittances, and natural $\log$ of industry value added.

Plot of the logarithms of the five time series is shown in Figure 2. The figure shows that the logarithms of real GDP (lnGDP), the real export (lnEXPT), the real imports (lnIMPT), the workers remittances (lnWREMIT) 
and the industry value added (lnIVA) exhibit strong upward trends. This provides subjective evidence that the five series tend to move together.

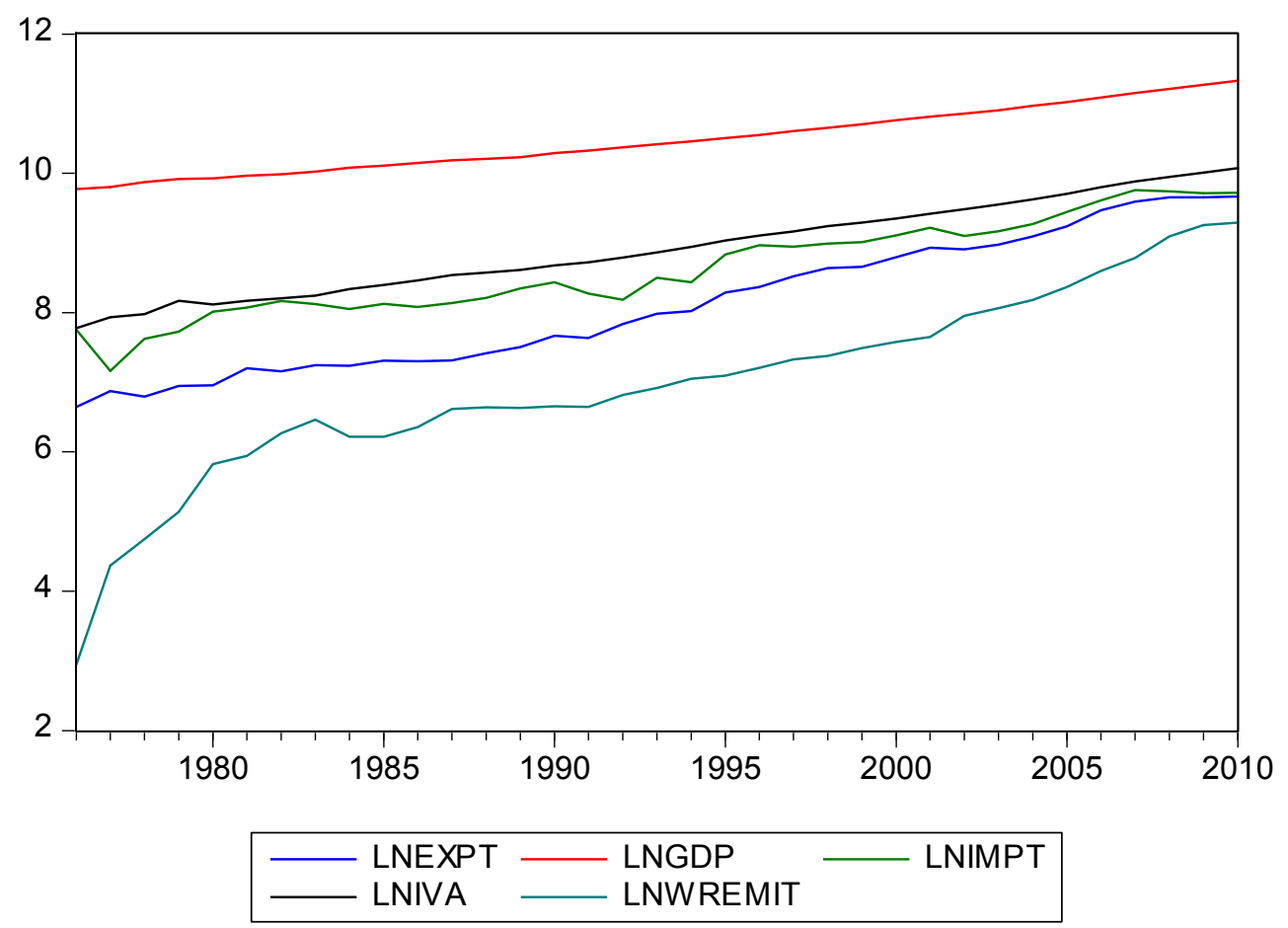

Figure 2. Natural log of real GDP, exports, import, worker remittance, and industry value added.

\section{Methodological Issues}

Testing for the order of integration. The first step, in the methodology, is to determine whether the variables used are stationary or not. If they are non-stationary, then the issue is to what degree they are integrated. This can be dealt with the ADF tests. If the calculated ADF statistic is less than its critical value, then $X$ (real GDP, exports, imports, workers remittance, and industry value added) is said to be stationary or integrated of order zero, i.e. I(0). If this is not the case, in that case the ADF test is performed on the first difference of $X$ (i.e. $\Delta X$ ). If $\Delta X$ is found to be stationary, then $X$ is integrated of order one, or I(1).

Testing for cointegration. If all the variables in a multivariate model are integrated of order one, i.e. I(1), after that, the next step is to find out whether they are cointegrated or not using Johansen's framework. The explanations of this approach can be found in researches of Johansen (1988) and Johansen and Juselius (1990).

If a stationary linear combination exists, then the non-stationary time series are alleged to be cointegrated. The stationary linear combination is named cointegrating equation and possibly interpreted as a long-run equilibrium relationship among variables. However, if there is no cointegration and long-run relationship among the variables, an ECM based on causality test is not appropriate. Therefore, causality test using Granger approach within the framework of VARs with the first difference is appropriate.

Testing for causality. The next question is to examine whether all the variables in the model should enter into a long-run equilibrium relationship. This can be conducted by testing linear restrictions on the long-run coefficients after they have been normalized. By using a likelihood ratio test, the hypothesis of long-run exclusion of each variable is tested. It is asymptotically distributed as $x^{2}$ with degrees of freedom equal to the number of restrictions tested. If the test statistic exceeds the $95 \%$ critical value, then those coefficients are 
significant implying that the concerned variables should be present in the long-run equilibrium relationship. The number of cointegrating relationships originated will result in a corresponding number of residual series, and therefore error correction terms (ECTs) are used in the subsequent VECM.

\section{Empirical Analysis}

The initial test is the stationary properties of the variables under consideration, i.e. their order of integration, after that test for cointegration among the variables. Finally, this paper checks Granger causality test among the variables in a VECM framework.

\section{Unit Root Test}

It is found that the variables (lnGDP, $\operatorname{lnEXPT}$, $\operatorname{lnIMPT}$, $\ln$ WREMIT, and $\operatorname{lnIVA}$ ) have trends in their level. ADF tests (Dickey \& Fuller, 1979) and PP tests are used for each of the five time series - real GDP, real exports, real imports, workers remittances, and industry value added to test for the presence of a unit root. To ensure that the residuals were white noise, the lag length for the ADF tests was selected.

The outcomes of ADF test by Engle and Granger (1987) with and without trend and the PP test again with and without trend are reported in Table 3.

Table 3

Unit Root Test

\begin{tabular}{|c|c|c|c|c|c|c|c|c|}
\hline \multirow[b]{2}{*}{ Variables } & \multicolumn{4}{|c|}{ ADF Test ( $t$-stat) } & \multicolumn{4}{|c|}{ PP test ( $t$-stat) } \\
\hline & $\begin{array}{l}\text { No. of } \\
\text { observations }\end{array}$ & (1) & $(2)$ & (3) & $\begin{array}{l}\text { No. of } \\
\text { observations }\end{array}$ & (1) & $(2)$ & (3) \\
\hline \multicolumn{9}{|l|}{$\operatorname{lnGDP}$} \\
\hline Level & 34 & 1.61 & 4.42 & 0.27 & 34 & 15.98 & 7.15 & 0.87 \\
\hline $\begin{array}{l}\text { First difference } \\
\operatorname{lnEXPT}\end{array}$ & 33 & 0.05 & $-4.14 * * *$ & $-5.88 * * *$ & 33 & -0.06 & $-4.36^{* * *}$ & $-5.91 * * *$ \\
\hline Level & 34 & 5.74 & 0.09 & -2.03 & 34 & 7.08 & 0.19 & -2.04 \\
\hline $\begin{array}{l}\text { First difference } \\
\operatorname{lnIMPT}\end{array}$ & 33 & -1.23 & $-7.78 * * *$ & $-7.93 * * *$ & 33 & $-4.53 * * *$ & $-7.67 * * *$ & $7.93 * * *$ \\
\hline Level & 34 & 1.85 & -0.44 & $-3.93 * *$ & 34 & 5.28 & 0.18 & $-3.94 * *$ \\
\hline $\begin{array}{l}\text { First difference } \\
\text { lnREMIT }\end{array}$ & 33 & $-7.47 * * *$ & $-9.65 * * *$ & $-9.50 * * *$ & 33 & $-6.99 * * *$ & $-9.07 * * *$ & $-9.50 * * *$ \\
\hline Level & 34 & 3.12 & $-3.88 * *$ & $-7.21 * * *$ & 34 & 2.19 & $-3.04 * *$ & $-5.74 * * *$ \\
\hline $\begin{array}{l}\text { First difference } \\
\text { lnIVA }\end{array}$ & 33 & $-6.46^{* * *}$ & $-7.90 * * *$ & $-3.34 * * *$ & 33 & $6.25^{* * *}$ & $-7.90 * * *$ & $-7.56^{* * *}$ \\
\hline Level & 34 & 5.10 & 1.84 & -0.92 & 34 & 13.60 & -0.06 & -2.80 \\
\hline First difference & 33 & 0.61 & $-4.39 * * *$ & $-4.74 * * *$ & 33 & $-2.85 * * *$ & $-8.77 * * *$ & $-11.57 * * *$ \\
\hline
\end{tabular}


PP tests at $1 \%$ level of significance. By using the Schwarz criterion (SC), optimal lag lengths are selected. As differencing once produces stationarity, it can be concluded that the variables under consideration are integrated of order one, i.e. I(1).

\section{Regression Analysis}

The unit root test results show that the data are non-stationary in their levels but stationary in their first differences. Therefore, the first difference of the log value is taken to estimate the regression model using ordinary least square (OLS) method. The regression equation is estimated as:

$$
\Delta \operatorname{lnGDP}{ }_{t}=\alpha_{0}+\alpha_{1} \Delta \operatorname{lnEXPT}_{t}+\alpha_{2} \Delta \operatorname{lnIMPT}_{t}+\alpha_{3} \Delta \ln \mathrm{WREMIT}_{t}+\alpha_{4} \Delta \operatorname{lnIVA}_{t}+\varepsilon_{t}
$$

The first difference of natural log the respective variable is denoted by $\Delta$ (delta). The constant and the coefficients of the regression equations are $\alpha_{0}$ and $\alpha_{1}, \alpha_{2}, \alpha_{3}$, and $\alpha_{4}$ respectively; $\varepsilon_{t}$ is the error term. The regression results of the model are shown in the Table 4.

The coefficient of the $\Delta \operatorname{lnEXPT}(-0.005491)$ implying that if there is $1 \%$ increase in growth rate of export, growth rate of GDP would face a decrease by $0.005 \%$, the associated probability is 0.8373 , which is not statistically significant. Likewise, if there is the $1 \%$ increase in growth rate of workers remittances, the growth rate of GDP would face a decrease by $0.015 \%$. The growth rate of GDP is increased by $0.02 \%$ and $0.18 \%$, if there is a $2 \%$ increase in the growth rate of import and industry value added respectively. The $P$-value for $\triangle \operatorname{lnIMPT}$ is 0.1353 . The $P$-value for $\Delta \operatorname{lnIVA}$ is 0.0079 which is statistically significant at $5 \%$ level. The growth rate of industry value added can contribute more than other variables to increase the growth rate of GDP.

Table 4

Regression Results

\begin{tabular}{lrlll}
\hline Variable & Coefficient & Std. error & $t$-statistic & Probability \\
\hline C & 0.035050 & 0.004969 & 7.053388 & 0.0000 \\
$\Delta$ lnEXPT & -0.005491 & 0.026502 & -0.207187 & 0.8373 \\
$\Delta$ lnIMPT & 0.020767 & 0.013517 & 1.536330 & 0.1353 \\
$\Delta$ lnWREMIT & -0.015752 & 0.008608 & -1.830001 & 0.0775 \\
$\Delta$ lnIVA & 0.189016 & 0.066196 & 2.855391 & 0.0079 \\
$r$-squared & 0.322067 & $F$-statistic & & 3.444277 \\
Adjusted $r$-squared & 0.228559 & Prob. $(F$-statistic) & & 0.020220 \\
S.E of regression & 0.012169 & Durbin-Watson stat & & 1.254179
\end{tabular}

Notes. Dependent variable: $\Delta \operatorname{lnGDP}$; method: least squares; sample (adjusted): 1976-2010; included observations: 34 after adjustments.

According to the OLS regression analysis, it can be seen that $\triangle \operatorname{lnEXPT,} \triangle \operatorname{lnIMPT}$, and $\triangle \ln$ WREMIT are not statistically significant at $5 \%$ level. So a combined $F$-statistic (Wald test) is performed to see the joint significance of the variables. Here, this paper predicts that variables are cointegrated. Having established that all variables in the study are integrated of $\mathrm{I}(1)$, this paper proceeds to test for cointegration among the variables within a VAR framework. The stationary linear combination is called the cointegrating equation and may be interpreted as a long-run equilibrium relationship among variables.

\section{Johansen Cointegration Test}

Having determined the order of integration of the variables, Johansen's cointegration test is applied to ascertain whether or not the variables share a common stochastic trend. The unit root results show that lnGDP, 
InEXPT, InIMPT, InWREMIT, and lnIVA are non-stationary in their levels but stationary in their first differences for Bangladesh. Therefore, multivariate cointegration test is conducted for these variables. The purpose of the cointegration test is to determine whether a group of non-stationary variables are cointegrated or not.

The optimal lag length of the level VAR system is determined using the Akaike's information criterion (AIC), and SC. Table 5 reports the number of cointegrating relationships among the variables under consideration.

Table 5

Johansen Cointegration Test

\begin{tabular}{|c|c|c|c|c|c|c|c|}
\hline \multirow{2}{*}{$\begin{array}{l}\text { Hypothesized } \\
\text { No. of Ces }\end{array}$} & \multirow{2}{*}{ Eigen value } & \multicolumn{3}{|c|}{$\begin{array}{c}\text { Unrestricted cointegration } \\
\text { rank test (Trace) }\end{array}$} & \multicolumn{3}{|c|}{$\begin{array}{c}\text { Unrestricted cointegration } \\
\text { rank test (Max-Eigen value) }\end{array}$} \\
\hline & & $\begin{array}{l}\text { Trace } \\
\text { statistics }\end{array}$ & $\begin{array}{l}\text { Critical } \\
\text { value at } 5 \%\end{array}$ & $p$-value & $\begin{array}{l}\text { Max-Eigen } \\
\text { value statistics }\end{array}$ & $\begin{array}{l}\text { Critical } \\
\text { value at } 5 \%\end{array}$ & $p$-value \\
\hline None * & 0.79 & 116.79 & 69.82 & 0.000 & 51.06 & 33.87 & 0.0002 \\
\hline At most $1 *$ & 0.69 & 65.73 & 47.86 & 0.0005 & 37.13 & 27.58 & 0.0022 \\
\hline At most 2 & 0.46 & 28.59 & 29.80 & 0.0683 & 19.81 & 21.13 & 0.0756 \\
\hline At most 3 & 0.23 & 8.78 & 15.49 & 0.3858 & 8.69 & 14.26 & 0.3123 \\
\hline At most 4 & 0.002 & 0.086 & 3.84 & 0.7685 & 0.086 & 3.84 & 0.7685 \\
\hline
\end{tabular}

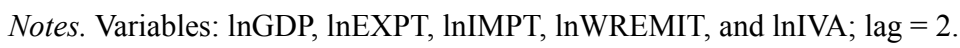

Results of both Trace and Max-Eigen value tests imply the existence of at least two cointegrating relationships among the variables in the series at $5 \%$ level of significance. This suggests that the series under consideration are driven by at least two common trends. Then this paper saves the residuals from the first two equations of the VAR. These are used as the error correction term in the succeeding tests for Granger causality.

Using Johansen's cointegration test, findings suggest that real GDP, real exports, real imports, remittance, and industry value added are cointegrated for Bangladesh, implying a long-run relationship amongst all these variables.

\section{Granger Causality Test}

Within a VAR framework, the concept of Granger causality is used to determine the direction of causation among $\operatorname{lnGDP}$, lnEXPT, InIMPT, lnWREMIT, and lnIVA, duly taking into account the stationary properties of the time series data. A VECM is used to test the granger causality among the variables under consideration. Table 6 reports the results of Granger causality tests based on error correction models.

Results indicate that the variable, $\triangle \operatorname{lnGDP}$ Granger cause by the variables $\operatorname{lnEXPT}$, $\operatorname{lnIMPT}$, $\operatorname{lnWREMIT}$, and $\operatorname{lnIVA}$, is significant at the $5 \%$ level. Similarly, $\triangle \operatorname{lnEXPT}$ is Granger cause by $\Delta \operatorname{lnGDP}, \Delta \operatorname{lnIMPT}$, $\triangle \ln$ WREMIT, and $\Delta \operatorname{lnIVA}$. The results show the null hypothesis that "Granger no-causality from $\Delta \operatorname{lnIMPT}$ to $\Delta \operatorname{lnGDP}, \Delta \operatorname{lnEXPT}$, and $\Delta \operatorname{lnIVA} "$ can be rejected at $5 \%$ level of significance. The results also show that $\Delta \ln W R E M I T$ is Granger cause by $\Delta \operatorname{lnIMPT}$ and $\triangle \operatorname{lnIVA}$ is Granger cause by the variables $\operatorname{lnEXPT}, \Delta \operatorname{lnIMPT}$, and $\Delta \ln$ WREMIT respectively. The results are significant at the $5 \%$ level and when $\Delta \ln$ WREMIT and $\Delta \operatorname{lnIVA}$ are dependent variables respectively.

These results indicate that exports and industrialization would accelerate the demands for imports of capital goods and technology which in turn, will increase the economic growth of Bangladesh. In Bangladesh, a significant portion of migrant worker remittances is spent for investment in trade and business and to finance import of capital goods. So a workers remittance is also used as a vehicle to accelerate economic growth. The 
result demonstrates that the variables are cointegrated, implying a long-run causal relationship among export, import, remittances, and industrialization on the economic growth of Bangladesh.

Table 6

Multivariate Granger Causality Test

\begin{tabular}{|c|c|c|c|c|c|}
\hline \multirow{3}{*}{ Dependent variable } & \multicolumn{5}{|c|}{ Source of causation } \\
\hline & $\Delta \operatorname{lnGDP}$ & $\Delta \ln \mathrm{EXPT}$ & $\Delta \operatorname{lnIMPT}$ & $\Delta \operatorname{lnWREMIT}$ & $\Delta \operatorname{lnIVA}$ \\
\hline & $\overline{x^{2}}$ & $x^{2}$ & $x^{2}$ & $x^{2}$ & $x^{2}$ \\
\hline$\Delta \operatorname{lnGDP}$ & - & $\begin{array}{c}2.71 * * \\
(0.2586)\end{array}$ & $\begin{array}{c}1.26^{* *} \\
(0.5303)\end{array}$ & $\begin{array}{c}3.97 * * \\
(0.1374)\end{array}$ & $\begin{array}{c}7.83^{* *} \\
(0.199)\end{array}$ \\
\hline$\Delta \operatorname{lnEXPT}$ & $\begin{array}{c}0.08 * * \\
(0.9603)\end{array}$ & - & $\begin{array}{c}0.49 * * \\
(0.7846)\end{array}$ & $\begin{array}{c}3.47 * * \\
(0.1764)\end{array}$ & $\begin{array}{c}0.09 * * \\
(0.9533)\end{array}$ \\
\hline$\Delta \operatorname{lnIMPT}$ & $\begin{array}{c}4.88 * * \\
(0.0871)\end{array}$ & $\begin{array}{l}1.82 * * \\
(0.40)\end{array}$ & - & $\begin{array}{l}9.16 \\
(0.0102)\end{array}$ & $\begin{array}{c}0.24 * * \\
(0.8871)\end{array}$ \\
\hline$\Delta \operatorname{lnWREMIT}$ & $\begin{array}{l}17.61 \\
(0.0002)\end{array}$ & $\begin{array}{l}9.98 \\
(0.0068)\end{array}$ & $\begin{array}{c}3.74 * * \\
(0.1541)\end{array}$ & ( & $\begin{array}{l}34.39 \\
(0.0000)\end{array}$ \\
\hline$\Delta \operatorname{lnIVA}$ & $\begin{array}{l}14.27 \\
(0.0008)\end{array}$ & $\begin{array}{c}3.70 * * \\
(0.1569) \\
\end{array}$ & $\begin{array}{c}1.72 * * \\
(0.4217) \\
\end{array}$ & $\begin{array}{c}2.29 * * \\
(0.2474)\end{array}$ & (1) \\
\hline
\end{tabular}

Notes. $P$-values are reported in the parenthesis; superscripts***, **, and * indicate rejection of null hypothesis at $1 \%, 5 \%$, and $10 \%$ level of significance.

\section{Conclusions}

In the light of the empirical results, it can be suggested that Bangladesh may continue with the imports of necessary raw materials for value addition and needed technology to expand capacity and to improve productivity to increase economic growth. It may also give full attention to boost up exports and worker remittances thereby achieving higher economic growth. The import of capital goods, technology, and efficient use of them can accelerate industrial production and value addition, which in turn, contribute to export earning and domestic economic growth. The results show that GDP will grow if import demand is derived from the export and industrial sectors. The export policies and export incentives for Bangladesh should be such that these can accelerate economic growth. However, caution must be implemented in interpreting these results owing to several limitations of the empirical analysis. First of all, the Granger causality approach is a theoretical in the sense that it is based solely on the statistical properties of the data and not on the structural relationships implied by economic theory. Secondly, wide-ranging structural transformations as well as changes in trade policy regimes have taken place in the economy of Bangladesh in the last two decades or so. Such policy shifts bring about structural breaks and, as a consequence, the estimated statistical coefficients may become unstable across different policy regimes. Finally, the longer period of time series data can produce better results in predicting the impact of trade, worker remittances, and industry value added on economic growth, and their causal and long-run relationships.

\section{References}

Abual-Foul, B. (2010). Testing the export-led growth hypothesis: Evidence from Jordan. Applied Economics Letters, 11, $393-396$. Ahmed, H. A., \& Uddin, G. S. (2008). Export, imports, remittance and growth in Bangladesh: An empirical analysis (Working Paper in International Trade Series, Department of Economics, Jadavpur University, Ministry of Commerce (GOI)-UNCTAD-DFID (UK), August 2008).

Ahmed, H. A., \& Uddin, G. S. (2009). Export, imports, remittance and growth in Bangladesh: An empirical analysis. Trade and Development Review, 2(2), 79-92.

Ahmed, N. (2001). Trade liberalization in Bangladesh: An investigation into trends. Dhaka: University Press Limited. 
Biru, P. P. (2011). The overseas migrant workers, remittances and the economy of Bangladesh. Dhaka University Journal of Business Studies, 15(2), 87-109.

Chandra, R. (2003). Reinvestigating export-led growth in India using a multivariate cointegration framework. Journal of Developing Areas, 37(1), 73-86.

Darrat, A. F., Hsu, M. K., \& Zhong, M. (2000). Testing export exogeneity in Taiwan: Further evidence. Applied Economics Letters, 7, 563-567.

Dickey, D. A., \& Fuller, W. A. (1979). Distributions of the estimators for autoregressive time series with a unit root. Journal of the American Statistical Association, 74, 427-431.

Engle, R., \& Granger, C. (1987). Cointegration and error correction representation: Estimation and testing. Econometrica, 55, 251-276.

Johansen, S. (1988). Statistical analysis of cointegrated vectors. Journal of Economic Dynamics and Control, 12, 131-154.

Johansen, S., \& Juselius, K. (1990). Maximum likelihood estimation and inference on cointegration: With an application to demand for money. Oxford Bulletin of Economics and Statistics, 52, 169-210.

Judith A. C., \& Ralhan, M. (2005). Direct and indirect causality between exports and economic output for Bangladesh and Sri Lanka (Horizon Matters, Econometrics Working Papers 0512, Department of Economics, University of Victoria).

Khan, I. K. (2002). Migration of workers from Bangladesh: Opportunities, challenges and policies' in employment and labour market dynamics: A review of Bangladesh's development (CPD and UPL, Dhaka, 2002).

Khawaja, A. M., \& Hiranya, K. N. (2005). Exports, imports, and economic growth in Portugal: Evidence from causality and cointegration analysis. Journal of Economic Modeling, 18, 613-623

Love, J., \& Chandra, R. (2005). Testing export-led growth in Bangladesh in a multivariate VAR framework. Journal of Asian Economics, 15(6), 1155-1168.

Mah, J. S. (2005). Export, expansion, economic growth and causality in China, Applied Economics Letters, 12, 105-107.

Mamun, K. A. Al, \& Nath, H. K. (2005). Export-led growth in Bangladesh: A time series analysis. Applied Economics Letters, 12(6), 361-364.

Perron, P. (1990). Testing for a unit root in a time series with a changing mean. Journal of Business and Economic Statistics, 8 , 153-162.

Quibria, M. G. (1986). Migrant workers and remittances: Issues for Asian developing countries. Asian Development Review, 4(1), 78-99.

Shirazi, N. S., \& Manap, T. A. (2005). Export-led growth hypothesis: Further econometric evidence from South Asia. The Developing Economies, 43(4), 472-488.

Sultan, P. (2008). Trade, industry and economic growth in Bangladesh. Journal of Economic Cooperation, 4, 71-92.

World Bank. (2005). Bangladesh growth and export competitiveness (Report No. 31394-BD, Poverty Reduction and Economic Management Sector Unit, South Asia Region). 